\title{
Histological study on the acute injection of aluminum sulfate on different organs of rats
}

\author{
Heba N. Gad EL-Hak ${ }^{a_{\star}}$; Samy A. Eladawy ${ }^{b}$; Hanan M. Rashwan'; Hagar E. Mohammed ${ }^{c}$ \\ ${ }^{a}$ Zoology department, faculty of science, Suez Canal University, Ismailia, Egypt. \\ ${ }^{b}$ Faculty of Veterinary medicine, Arish University, North Sinai, Egypt. \\ ${ }^{c}$ Zoology department, faculty of Science, Arish University, North Sinai, Egypt.
}

\section{ARTICLE INFO}

Article history:

Received 24 December 2019

Received in revised form 9 January 2020

Accepted 10 January 2020

Available online 17 January 2020

\section{Keywords}

aluminum sulfate;

male rats;

female rats;

intraperitoneal (IP) route;

histological damage inspection

\begin{abstract}
Aluminum sulfate is known to create toxic effects on several systems of experimental animals. This research was undertaken to examine the absorption of aluminum confirmed by histological examination of rat's organ after single intraperitoneal (IP) injection of $\mathrm{Al}_{2}\left(\mathrm{SO}_{4}\right)_{3}$. Male and female rats received a single (IP) injections of $(23,67$, $200,600,1800,5400,16200,48600) \mathrm{mg} / \mathrm{kg}$ b.wt. $\mathrm{Al}_{2}\left(\mathrm{SO}_{4}\right){ }_{3}$ dissolved in distilled water ( $n=6 /$ sex/group). After 14 days male and female tissues were collected for aluminum (Al) content and histological damage assay. Its effect was evaluated in liver, kidney, lungs, spleens, heart, stomach, intestine, brain, testis, ovary and uterus compared to those of control rats. No mortality was recorded during the two weeks. Injection of higher doses of $\mathrm{Al}_{2}\left(\mathrm{SO}_{4}\right)_{3}$ produced burning of skin around the injection area for both male and female rats. Rats treated with $(1800,5400,16200,48600)$ $\mathrm{mg} / \mathrm{kg}$ b.wt. $\mathrm{Al}_{2}\left(\mathrm{SO}_{4}\right)_{3}$ showed a significant increase of aluminum accumulation and histological change in male and female rats, stomach, small intestine, liver, and lung. A short term use of low dose of $\mathrm{Al}_{2}\left(\mathrm{SO}_{4}\right)_{3}$ is safe and induce mild histopathological alteration for the different body organs. On the other hand, severe histopathologial alteration synchronized with aluminum accumulation in the body organs are induced by using a single higher dose of $\mathrm{Al}_{2}\left(\mathrm{SO}_{4}\right)_{3}$.
\end{abstract}

\section{Introduction}

Aluminum (Al), the most abundant metal on earth that makes up 8.13 percent of the crust, may enter the human body through food, drinking water, and Al-containing drugs [1]. As a result of the widespread use of Aluminum a wellestablished neurotoxic model in experimental animals is reported [2, 3]. Chronic exposition to Aluminum can lead to alterations in skeletal, nervous, hematopoietic and respiratory systems [4,5]. Aluminum accumulation in the liver is associated with a number of biochemical changes, including the release of liver injury enzyme markers and alteration of oxidant status. [6]. Moreover, Chronic exposure to aluminum is associated with neurodegenerative disorders $[7,8]$, hepatic toxicity [6] and renal toxicity.

A number of authors have reported administration of aluminum sulphate mediated toxicity in rats $[9,10]$. Mahor and Ali [11] suggested that rats received aluminium sulphate in a dose of $98 \mathrm{mg} / \mathrm{kg}$ of body weight orally for 30 and 60 days has significantly elevated the normal levels of liver enzymes.

\footnotetext{
* Corresponding authors at: Suez Canal University

E-mail addresses: heba nageh@hotmail.com (Heba N.Gad EL-Hak)
}

Male wistar rats Orally received aluminium sulphate in drinking water decreased the rat fertility $[12,13]$.

There is a limited research on the acute effect of IP injection of $\mathrm{Al}_{2}\left(\mathrm{SO}_{4}\right)_{3}$. The above literature shows that most of the previous studies have focused on studying the effects of repeated $\mathrm{Al}_{2}\left(\mathrm{SO}_{4}\right)_{3}$ treatment, while the acute toxicity of a single dose of $\mathrm{Al}_{2}\left(\mathrm{SO}_{4}\right)_{3}$ has not been tested. The purpose of present study is to investigate the histological effect of single IP injection of $\mathrm{Al}_{2}\left(\mathrm{SO}_{4}\right)_{3}$ to the male and female rats in a short period of time.

\section{Materials and methods}

\subsection{Experimental design}

Healthy male and virgin female albino rats weighted between $250 \pm 10 \mathrm{~g}$ were used. Animals were purchased from the animal house of Zoology Department, Faculty of Science, Suez Canal University, Ismailia, Egypt.. They were separated into plastic cages with stainless steel mesh lids in a ventilated room. The room was held at about $25^{\circ} \mathrm{C}$ and 45 to 60 percent relative humidity at $12 \mathrm{~h}$ of a light-dark period. All animals had free access to tap water and the same type of food, throughout the study. The animals were kept in their cages for at least 7 
days prior to dosing, for their acclimatization to the laboratory conditions. All experiments were performed in compliance with the guidelines of the Guide to the Care and Use of Laboratory Animals (Council 2010) and approved in accordance with the Ethical Rules for the Management of Experimental Animals, Zoology Department, Faculty of Science, Suez Canal University, Ismailia, Egypt. Rats were randomly divided into control and treated group. The control group contains six male and six female rats without any treatment. The treated groups consisted of eight male groups and eight female groups of six rats each. Each group received a single IP injection of $(23,67,200,600,1800,5400,16200$ and $48600) \mathrm{mg} / \mathrm{kg}$ b.wt. $\mathrm{AL}_{2}\left(\mathrm{So}_{4}\right) 3$ dissolved in distilled water. Prior dosing, rats were weighed and each dose of $\mathrm{Al}_{2}\left(\mathrm{SO}_{4}\right)_{3}$ was determined in accordance with the animal's weight. $\mathrm{Al}_{2}\left(\mathrm{SO}_{4}\right)_{3}$ was purchased from Sigma Aldrich with high purity in the form of powder. Upon dosing, the animals were monitored individually with special attention during the first 4 hours and regularly during the first 72 hours, and at least once daily for 14 days of any change in their behavior. After 14 days, all animals fasted for $24 \mathrm{~h}$ and blood was collected by venipuncture from all animals and processed for the determination of the aluminum concentration in the whole blood by Langmyhr and Tsalev [14] after anesthetization with 4 percent halothane. Then, Rats were sacrificed by decapitation. Part of the forebrains, heart, lung, liver, kidney, spleen, stomach, small intestine epidydimis, testes, uterus and ovary were isolated and fixed in $10 \%$ of phosphate buffered formalin for 2 days for histological preparation for light microscopic examination [EL-Hak, Moustafa [15, 16, 17]. $0.5 \mathrm{~g}$ of each rat tissue was used for the assessment of aluminum concentrations [18]. Concentrations of aluminum in rat tissue were as $\mu \mathrm{g}$ per $\mathrm{g}$ of wet weight. Estimates are made using the Perkin Elmer AS 2380 fire absorption spectrophotometer [19]. Determining the concentration of $\mathrm{AL}$ using the procedures set out in the Standard Requirements section of the Standards were prepared by diluting the stock standard solution with deionized water [20]. Deionized water was used as a blank solution. Blank determination was made for the calibration of the instrument. All the reagents were obtained from Merck, Darmstadt (Germany).

\subsection{Statistical analysis}

The statistical analysis was carried out using SPSS version 15 (SPSS Inc., Chicago, USA). One-way variance analysis (ANOVA) was used to analyze the difference in determining indices between experimental groups. Subsequently, individual differences between the groups were assessed using the Dunnette test. Significance was considered to be $p<0.05$. All data were reported as mean \pm standard error of mean (SEM).

\section{Result}

No mortality was recorded during the study and $\mathrm{Al}_{2}\left(\mathrm{SO}_{4}\right)_{3}$ treated male and female rats showed no change in body weight and behavior compared to the control group with skin burning around the injection area, which increased by increasing the dose Fig. (1).
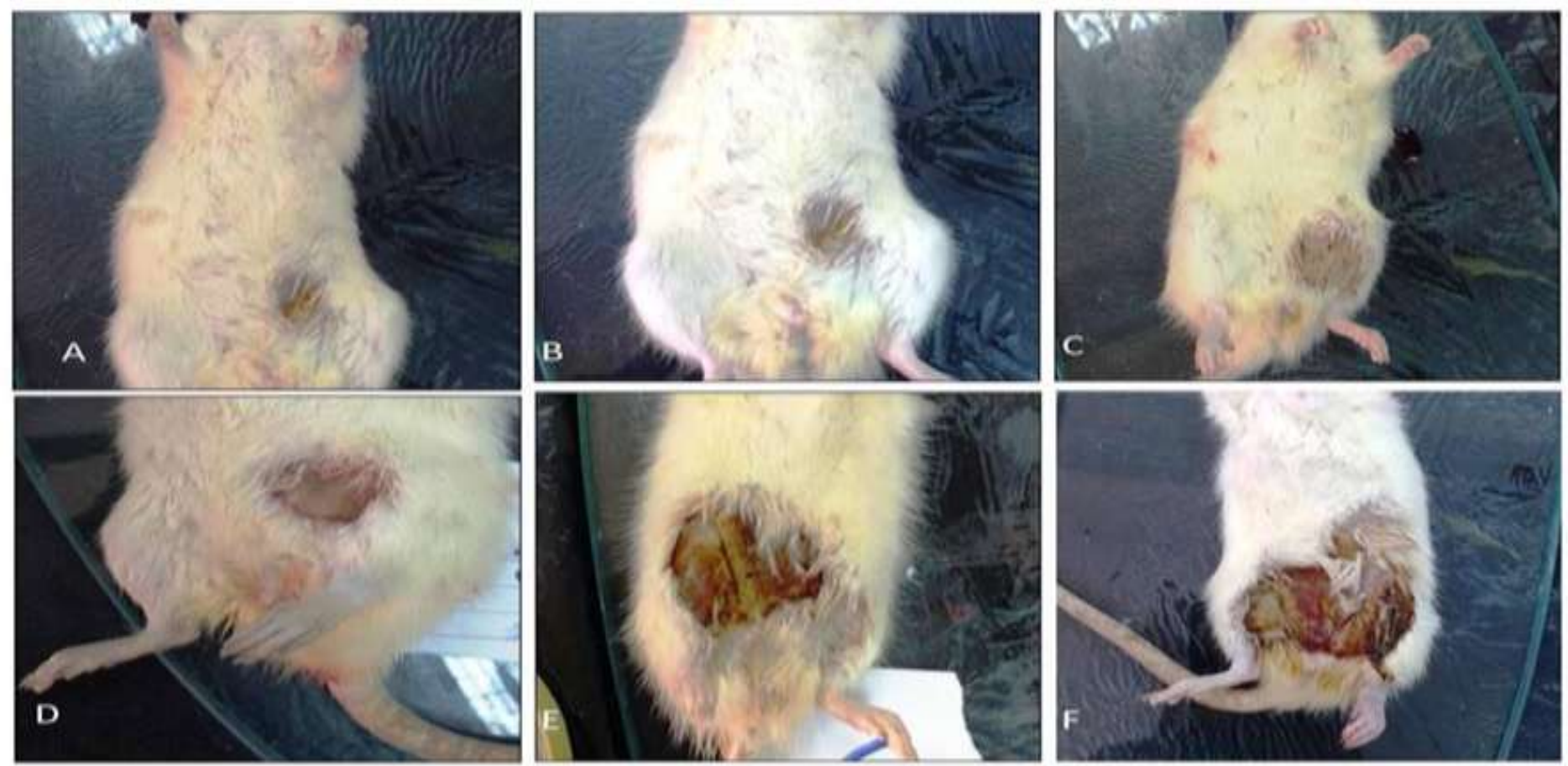

Figure (1): Modulatory effects of $\mathrm{Al}_{2}\left(\mathrm{SO}_{4}\right)_{3}$ burning of the injected skin area increased by increasing the dose and persist for 14 days with no difference between the male and female rats in the burning appearance. $(A)$ : Male rats injected with $600 \mathrm{mg} / \mathrm{kg}$. (B): Female rats injected with $600 \mathrm{mg} / \mathrm{kg}$. (C): Male rats injected with $5400 \mathrm{mg} / \mathrm{kg}$. (D): Female rats injected with $5400 \mathrm{mg} / \mathrm{kg}$. (E): Female rats injected with $48600 \mathrm{mg} / \mathrm{kg}$. (F): male rats injected with $48600 \mathrm{mg} / \mathrm{kg}$. 


\subsection{Aluminum content in different organs}

Al was significantly increased $p<0.05$ in blood when the higher doses of $\mathrm{Al}_{2}\left(\mathrm{SO}_{4}\right)_{3}$ were given to the male and female rats (Table 1 ).

Table (1) Influences of a single IP dose of $\mathrm{Al}_{2}\left(\mathrm{SO}_{4}\right)_{3}$ on the aluminium level $(\mu \mathrm{g} / \mathrm{L})$ in the rats' blood.

\begin{tabular}{ccl}
\hline Groups & Male & Female \\
\hline Control & $0.0 \pm 0.0$ & $0.0 \pm 0.0$ \\
$23 \mathrm{mg} / \mathrm{kg} \mathrm{Al}_{2}\left(\mathrm{SO}_{4}\right)_{3}$ & $1.637 \pm 0.4^{*}$ & $1.725 \pm 0.3^{*}$ \\
$67 \mathrm{mg} / \mathrm{kg} \mathrm{Al}\left(\mathrm{SO}_{4}\right)_{3}$ & $1.435 \pm 0.2^{*}$ & $1.40 \pm 0.2^{*}$ \\
$200 \mathrm{mg} / \mathrm{kg} \mathrm{Al}_{2}\left(\mathrm{SO}_{4}\right)_{3}$ & $1.317 \pm 0.2^{*}$ & $1.73 \pm 0.2^{*}$ \\
$600 \mathrm{mg} / \mathrm{kg} \mathrm{Al}_{2}\left(\mathrm{SO}_{4}\right)_{3}$ & $1.435 \pm 0.1^{*}$ & $2.13 \pm 0.2^{*}$ \\
$1800 \mathrm{mg} / \mathrm{kg} \mathrm{Al}_{2}\left(\mathrm{SO}_{4}\right)_{3}$ & $1.775 \pm 0.2^{*}$ & $2.08 \pm 0.2^{*}$ \\
$5400 \mathrm{mg} / \mathrm{kg} \mathrm{Al}_{2}\left(\mathrm{SO}_{4}\right)_{3}$ & $1.318 \pm 0.1^{*}$ & $2.27 \pm 0.15^{*}$ \\
$16200 \mathrm{mg} / \mathrm{kg} \mathrm{Al}_{2}\left(\mathrm{SO}_{4}\right)_{3}$ & $1.591 \pm 0.2^{*}$ & $1.233 \pm 0.1^{*}$ \\
$48600 \mathrm{mg} / \mathrm{kg} \mathrm{Al}_{2}\left(\mathrm{SO}_{4}\right)_{3}$ & $2.208 \pm 0.3^{*}$ & $1.1563 \pm 0.1^{*}$
\end{tabular}

Data are represented mean \pm SE. $\left(^{*}\right)$ represented significant $p \leq 0.05$ compared to control group.

Increased $\mathrm{Al}$ in several tissues from the higher dose was demonstrated in male and female rats (Table 2 and 3). Liver aluminum content in male and female rats treated with (16200 and 48600$) \mathrm{mg} / \mathrm{kg} \mathrm{Al} 2\left(\mathrm{SO}_{4}\right)_{3}$ was significantly increased compared to control rats $(P<0.05)$.

The $\mathrm{Al}$ concentration of the kidney from the $\mathrm{Al}_{2}\left(\mathrm{SO}_{4}\right)_{3}$ treated male and female rats was nonsignificant increased $(p>0.05)$. The Al concentration was markedly significant $(P<0.05)$ in treated male rats with 48600 $\mathrm{mg} / \mathrm{kg} \mathrm{Al} 2\left(\mathrm{SO}_{4}\right)_{3}$ and treated female rats with 16200 and $48600 \mathrm{mg} / \mathrm{kg} \mathrm{mg} / \mathrm{kg} \mathrm{Al}{ }_{2}\left(\mathrm{SO}_{4}\right)_{3}$ compared with the control group.

Aluminium concentration in the heart tissue of treated male and female rats with 16200 and $48600 \mathrm{mg} / \mathrm{kg}$ $\mathrm{Al}_{2}\left(\mathrm{SO}_{4}\right)_{3}$ treatment significantly $(P<0.05)$ increased $(P<0.05)$ compared to control rats.

Moreover, Aluminum content in the lungs significantly increased $(P<0.05)$ in treated male groups 1800, 5400, 16200 and $48600 \mathrm{mg} / \mathrm{kg} \mathrm{Al}\left(\mathrm{SO}_{4}\right)_{3}$ and treated female group with 16200 and $48600 \mathrm{mg} / \mathrm{kg} \mathrm{Al}{ }_{2}\left(\mathrm{SO}_{4}\right)_{3}$.

Aluminum content in spleen significantly increased in treating male and female groups with $48600 \mathrm{mg} / \mathrm{kg}$ $\mathrm{Al}_{2}\left(\mathrm{SO}_{4}\right)_{3}$.

Aluminum content in testis, ovaries and uterus was not significantly increased $(p>0.05)$ in all $\mathrm{Al}_{2}\left(\mathrm{SO}_{4}\right)_{3}$ treated groups. Aluminum content in the forebrain, stomach and small intestine showed a significant increase $(P<0.05)$ in all $\mathrm{Al}_{2}\left(\mathrm{SO}_{4}\right)_{3}$ treated male and female rats.

\subsection{The histological results:}

The histological finding of the liver of treated rats with $(5400,16200,48600) \mathrm{mg} / \mathrm{kg}$ b.wt. $\mathrm{Al}_{2}\left(\mathrm{SO}_{4}\right)_{3}$ revealed mild portal infiltration with inflammatory cells Fig. (2) and the liver of treated rats with with $(23,67,200,600,1800)$ $\mathrm{mg} / \mathrm{kg}$ b.wt. $\mathrm{Al}_{2}\left(\mathrm{SO}_{4}\right)_{3}$ in both sexes revealed normal histological structure of the hepatic lobule Fig. (3) compared with control untreated rats. Liver sections of the control group showed Central veins located in the center of hepatic lobules. Hepatocytes were extended in a radial manner from the center towards the periphery of the lobules.

Table (2) Influences of a single IP dose of $\mathrm{Al}_{2}\left(\mathrm{SO}_{4}\right)_{3}$ on the aluminium level $(\mu \mathrm{g} / \mathrm{g})$ in the tissue of male rats.

\begin{tabular}{|c|c|c|c|c|c|c|c|c|c|}
\hline Groups & Liver & Kidney & Heart & Lung & Spleen & Testis & Brain & Stomach & Small intestine \\
\hline Control & $0.0 \pm 0.0$ & $0.0 \pm 0.0$ & $0.0 \pm 0.0$ & $0.0 \pm 0.0$ & $0.0 \pm 0.0$ & $0.0 \pm 0.0$ & $0.0 \pm 0.0$ & $0.0 \pm 0.0$ & $0.0 \pm 0.0$ \\
\hline $\begin{array}{l}23 \mathrm{mg} / \mathrm{kg} \\
\mathrm{Al}_{2}\left(\mathrm{SO}_{4}\right)_{3}\end{array}$ & $0.106 \pm 0.0$ & $0.373 \pm 0.1$ & $0.237 \pm 0.1$ & $0.473 \pm 0.1$ & $0.125 \pm 0.1$ & $0.351 \pm 0.1$ & $0.853 \pm 0.16^{*}$ & $1.129 \pm 0.4^{*}$ & $1.351 \pm 0.2^{*}$ \\
\hline $\begin{array}{l}67 \mathrm{mg} / \mathrm{kg} \\
\mathrm{Al}_{2}\left(\mathrm{SO}_{4}\right)_{3}\end{array}$ & $0.158 \pm 0.1$ & $0.276 \pm 0.1$ & $0.240 \pm 0.0$ & $0.293 \pm 0.1$ & $0.183 \pm 0.1$ & $0.056 \pm 0.0$ & $1.808 \pm 0.17^{*}$ & $1.455 \pm 0.2^{*}$ & $1.469 \pm 0.2^{*}$ \\
\hline $\begin{array}{c}200 \mathrm{mg} / \mathrm{kg} \\
\mathrm{Al}_{2}\left(\mathrm{SO}_{4}\right)_{3}\end{array}$ & $0.835 \pm 0.2$ & $0.150 \pm 0.1$ & $0.269 \pm 0.0$ & $0.477 \pm 0.1$ & $0.235 \pm 0.1$ & $0.266 \pm 0.1$ & $1.216 \pm 0.06^{*}$ & $1.800 \pm 0.2^{*}$ & $1.350 \pm 0.1^{*}$ \\
\hline $\begin{array}{c}600 \mathrm{mg} / \mathrm{kg} \\
\mathrm{Al}_{2}\left(\mathrm{SO}_{4}\right)_{3}\end{array}$ & $1.196 \pm 0.1^{*}$ & $0.226 \pm 0.1$ & $0.259 \pm 0.1$ & $0.482 \pm 0.2$ & $0.318 \pm 0.1$ & $0.238 \pm 0.0$ & $1.379 \pm 0.15^{\star}$ & $1.550 \pm 0.3^{*}$ & $1.386 \pm 0.1^{*}$ \\
\hline $\begin{array}{c}1800 \mathrm{mg} / \mathrm{kg} \\
\mathrm{Al}_{2}\left(\mathrm{SO}_{4}\right)_{3}\end{array}$ & $1.113 \pm 0.3^{*}$ & $0.156 \pm 0.7$ & $0.274 \pm 0.1$ & $0.565 \pm 0.1^{*}$ & $0.240 \pm 0.1$ & $0.281 \pm 0.1$ & $1.863 \pm 0.23^{*}$ & $1.593 \pm 0.2^{*}$ & $1.337 \pm 0.2^{*}$ \\
\hline $\begin{array}{c}5400 \mathrm{mg} / \mathrm{kg} \\
\mathrm{Al}_{2}\left(\mathrm{SO}_{4}\right)_{3}\end{array}$ & $1.28 \pm 0.1^{*}$ & $0.310 \pm 0.1$ & $0.271 \pm 0.1$ & $0.640 \pm 0.1^{*}$ & $0.041 \pm 0.0$ & $0.244 \pm 0.1$ & $1.900 \pm 0.26^{*}$ & $1.470 \pm 0.2^{*}$ & $1.269 \pm 0.03^{*}$ \\
\hline $\begin{array}{c}16200 \mathrm{mg} / \mathrm{kg} \\
\mathrm{Al}_{2}\left(\mathrm{SO}_{4}\right)_{3}\end{array}$ & $1.035 \pm 0.3^{*}$ & $0.291 \pm 0.1$ & $0.347 \pm 0.1^{*}$ & $0.750 \pm 0.2^{*}$ & $0.291 \pm 0.1$ & $0.220 \pm 0.2$ & $1.317 \pm 0.11^{*}$ & $1.543 \pm 0.2^{*}$ & $1.203 \pm 0.1^{*}$ \\
\hline $\begin{array}{c}48600 \mathrm{mg} / \mathrm{kg} \\
\mathrm{Al}_{2}\left(\mathrm{SO}_{4}\right)_{3}\end{array}$ & $2.271 \pm 0.1^{*}$ & $0.441 \pm 0.1^{*}$ & $0.358 \pm 0.1^{*}$ & $1.1816 \pm 0.0^{*}$ & $0.381 \pm 0.09^{*}$ & $0.160 \pm 0.1$ & $2.016 \pm 0.15^{\star}$ & $1.150 \pm 0.0^{*}$ & $1.479 \pm 0.1^{*}$ \\
\hline
\end{tabular}

Data are represented mean \pm SE. $\left(^{*}\right)$ represented significant $p \leq 0.05$ compared to control group. 
Table (3) Influences of a single IP dose of $\mathrm{Al}_{2}\left(\mathrm{SO}_{4}\right)_{3}$ on the aluminium level $(\mu \mathrm{g} / \mathrm{g})$ in the tissue of female rats.

\begin{tabular}{|c|c|c|c|c|c|c|c|c|c|c|}
\hline Groups & Liver & Kidney & Heart & Lung & Spleen & Ovary & Uterus & Brain & Stomach & $\begin{array}{c}\text { Small } \\
\text { intestine }\end{array}$ \\
\hline Control & $0.00 \pm 0.0$ & $0.0 \pm 0.0$ & $0.0 \pm 0.0$ & $0.0 \pm 0.0$ & $0.0 \pm 0.0$ & $0.0 \pm 0.0$ & $0.0 \pm 0.0$ & $0.0 \pm 0.0$ & $0.0 \pm 0.0$ & $0.0 \pm 0.0$ \\
\hline $\begin{array}{c}23 \mathrm{mg} / \mathrm{kg} \\
\mathrm{Al}_{2}\left(\mathrm{SO}_{4}\right)_{3} \\
\end{array}$ & $0.296 \pm 0.2$ & $0.148 \pm 0.1$ & $0.157 \pm 0.1$ & $0.226 \pm 0.19$ & $0.0 \pm 0.0$ & $0.260 \pm 0.1$ & $0.203 \pm 0.1$ & $0.965 \pm 0.3^{*}$ & $0.291 \pm 0.1$ & $0.286 \pm 0.1$ \\
\hline $\begin{array}{l}67 \mathrm{mg} / \mathrm{kg} \\
\mathrm{Al}_{2}\left(\mathrm{SO}_{4}\right)_{3}\end{array}$ & $0.748 \pm 0.2$ & $0.007 \pm 0.0$ & $0.269 \pm 0.0$ & $0.610 \pm 0.1$ & $0.235 \pm 0.1$ & $0.076 \pm 0.1$ & $0.210 \pm 0.1$ & $1.620 \pm 0.2^{*}$ & $0.058 \pm 0.0$ & $1.455 \pm 0.3^{*}$ \\
\hline $\begin{array}{r}200 \mathrm{mg} / \mathrm{kg} \\
\mathrm{Al}_{2}\left(\mathrm{SO}_{4}\right)_{3}\end{array}$ & $0.735 \pm 0.2$ & $0.345 \pm 0.1$ & $0.275 \pm 0.1$ & $0.41 \pm 0.1$ & $0.041 \pm 0.0$ & $0.127 \pm 0.1$ & $0.261 \pm 0.0$ & $1.595 \pm 0.1^{*}$ & $1.013 \pm 0.4^{*}$ & $1.360 \pm 0.4^{*}$ \\
\hline $\begin{array}{r}600 \mathrm{mg} / \mathrm{kg} \\
\mathrm{Al}_{2}\left(\mathrm{SO}_{4}\right)_{3} \\
\end{array}$ & $0.81 \pm 0.3$ & $0.159 \pm 0.1$ & $0.168 \pm 0.1$ & $0.501 \pm 0.1$ & $0.116 \pm 0.1$ & $0.230 \pm 0.1$ & $0.268 \pm 0.1$ & $1.490 \pm 0.2$ & $1.730 \pm 0.2^{*}$ & $1.871 \pm 0.3^{*}$ \\
\hline $\begin{array}{c}1800 \mathrm{mg} / \mathrm{kg} \\
\mathrm{Al}_{2}\left(\mathrm{SO}_{4}\right)_{3}\end{array}$ & $0.41 \pm 0.4$ & $0.320 \pm 0.1$ & $0.229 \pm 0.1$ & $0.570 \pm 0.2$ & $0.200 \pm 0.1$ & $0.257 \pm 0.1$ & $0.246 \pm 0.1$ & $1.173 \pm 0.3 *$ & $1.771 \pm 0.2$ & $1.78 \pm 0.2 *$ \\
\hline $\begin{array}{c}5400 \mathrm{mg} / \mathrm{kg} \\
\mathrm{Al}_{2}\left(\mathrm{SO}_{4}\right)_{3}\end{array}$ & $0.53 \pm 0.2$ & $0.314 \pm 0.1$ & $0.331 \pm 0.1$ & $0.614 \pm 0.2$ & $0.150 \pm 0.1$ & $0.278 \pm 0.1$ & $0.236 \pm 0.1$ & $0.990 \pm 0.19 *$ & $2.076 \pm 0.35^{*}$ & $1.50 \pm 0.1 *$ \\
\hline $\begin{array}{c}16200 \mathrm{mg} / \mathrm{kg} \\
\mathrm{Al}_{2}\left(\mathrm{SO}_{4}\right)_{3}\end{array}$ & $1.31 \pm 0.3^{*}$ & $0.249 \pm 0.1$ & $0.363 \pm 0.1 *$ & $0.630 \pm 0.3$ & $0.083 \pm 0.1$ & $0.259 \pm 0.1$ & $0.193 \pm 0.1$ & $2.073 \pm 0.26^{*}$ & $2.220 \pm 0.16^{*}$ & $1.72 \pm 0.6^{*}$ \\
\hline $\begin{array}{c}48600 \mathrm{mg} / \mathrm{kg} \\
\mathrm{Al}_{2}\left(\mathrm{SO}_{4}\right)_{3}\end{array}$ & $1.641 \pm 0.3^{*}$ & $1.441 \pm 0.3^{*}$ & $0.479 \pm 0.1 *$ & $0.7851 \pm 0.1 *$ & $0.418 \pm 0.1 *$ & $0.169 \pm 0.0$ & $0.217 \pm 0.0$ & $1.885 \pm 0.25 *$ & $1.975 \pm 0.28 *$ & $2.12 \pm 0.2 *$ \\
\hline
\end{tabular}

Data are represented mean \pm SE. $\left({ }^{*}\right)$ represented significant $p \leq 0.05$ compared to control group.
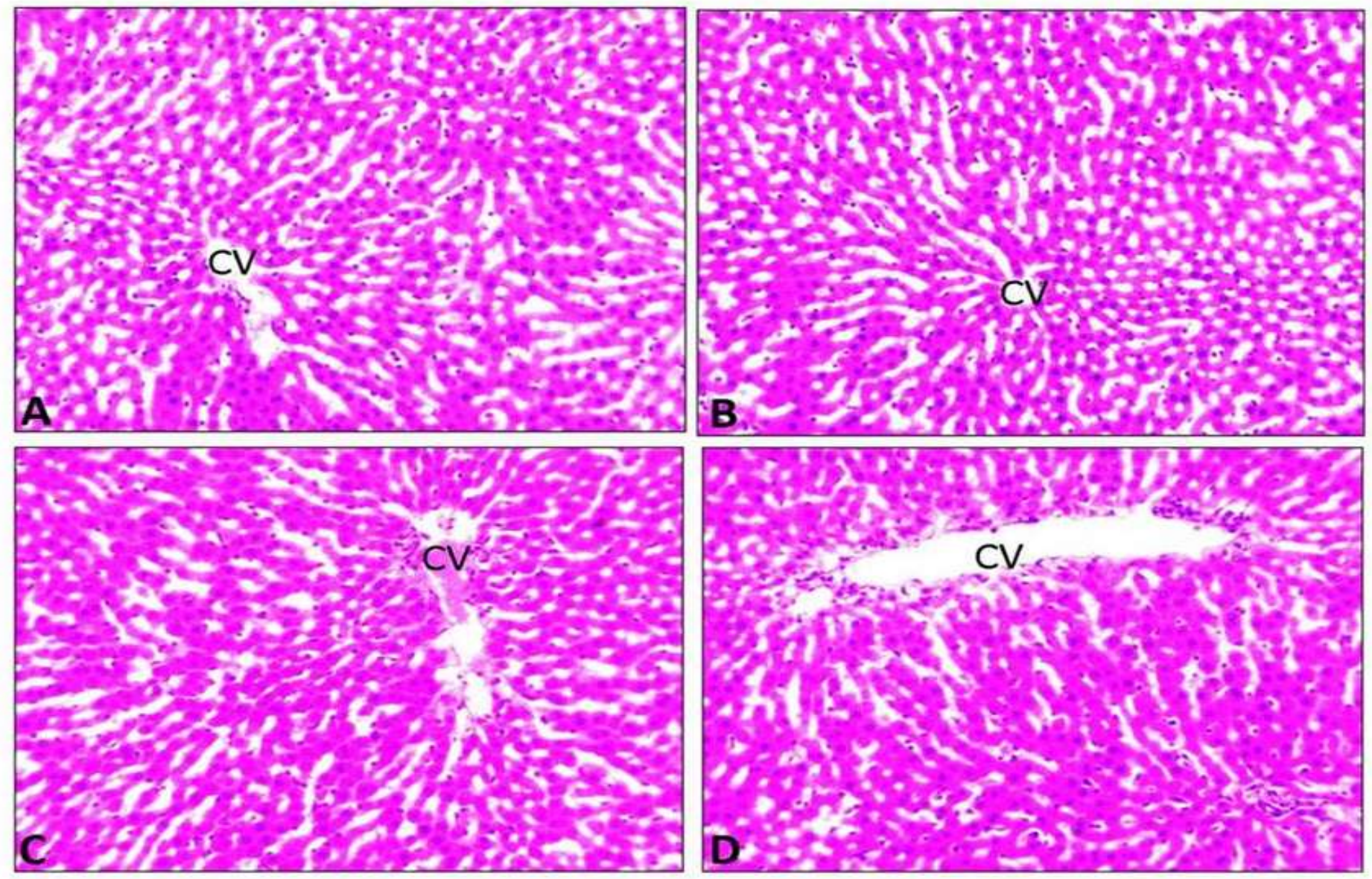

Figure (2): A photomicrograph of liver section from a control $(A)$ : male rat and $(B)$ : female rats showing normal histological structure of hepatic lobule surrounded the central vein (CV). Histopathological examination of liver of treated (C): male rat and (D): female rats IP with $48600 \mathrm{mg} / \mathrm{kg}$ b.wt. $\mathrm{Al}_{2}\left(\mathrm{SO}_{4}\right)_{3}$ showed normal histological structure of hepatic lobules encompassing the central vein (CV) (HX\&E, x200). 

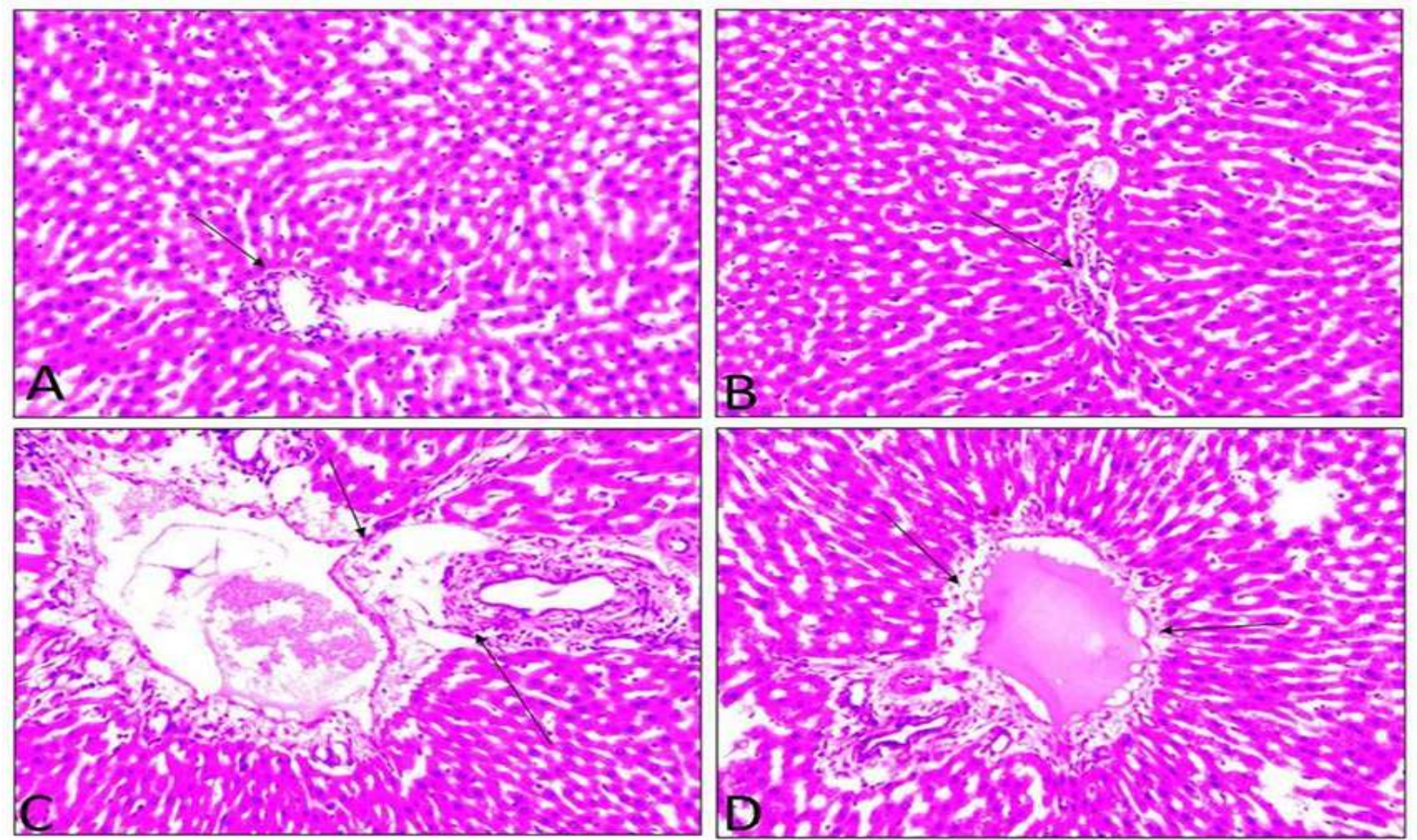

Figure (3): A photomicrograph of liver section from a control $(A)$ : male rat and $(B)$ : female rats showing normal histological structure of hepatic cell surrounded the portal area $(\leftarrow)$. Histopathological examination of liver treated $(C)$ : male rat and (D): female rats IP with $48600 \mathrm{mg} / \mathrm{kg}$ b.wt. $\mathrm{Al}_{2}\left(\mathrm{SO}_{4}\right)_{3}$ showed infiltration of inflammatory cells surrounded the portal area $(\leftarrow)(H X \& E, x 200)$.

They were arranged in the form of hepatic plates. Hepatic plates were separated by blood sinusoids that drained into the central vein. Portal tracts were demonstrated at the periphery of the lobules comprising four components; the largest of which was a branch of the portal vein, which had a thin wall and a long lumen with a flattened endothelial lining. There were a thick wall and narrow lumen in the branch of the hepatic artery. Bile duct exhibited cuboidal lining epithelium.

The histological finding of the rat kidney which injected IP with (23, 67, 200, 600, 1800, 5400, 16200 and 48600) $\mathrm{mg} / \mathrm{kg}$ b.wt. $\mathrm{Al}_{2}\left(\mathrm{SO}_{4}\right)_{3}$ in both sexes were presented in Fig. (4) all within the normal histological limit of cortical tissue and glomerulus comparing to the kidney tissue of the control male and female rats. Kidney sections of control rats had typical histological architectures of the Malpighian renal corpuscles with glomerulus as well as proximal and distal convoluted tubules. Proximal convoluted tubules have narrow lumen and are lined with pyramidal cells having deeply acidophilic cytoplasm and well formed apical brush border. Distal tubules have wider lumen and are lined with cuboidal cells having less acidophilic cytoplasm.

Light microscopic examination of the rat heart, which injected IP with (23, 67, 200, 600, 1800, 5400, 16200 and 48600) $\mathrm{mg} / \mathrm{kg}$ b.wt. $\mathrm{Al}_{2}\left(\mathrm{SO}_{4}\right)_{3}$ in both sexes were demonstrated in Fig. (5) showed normal histological architecture of cardiac myocytes compared to the heart tissue of the control male and female rats. The cardiomyocytes appeared as branching with clear striations. Adjacent cells were separated by connective tissue containing blood vessels.

Light microscopic examination of the lung of rats IP injected with $(23,67,200,600$ and 1800) mg/kg b.wt. $\mathrm{Al}_{2}\left(\mathrm{SO}_{4}\right)_{3}$ in both sexes showed normal histological architecture of lung tissues compared to the control male and female rats. The lung of rats injected IP with (5400, $16200,48600) \quad \mathrm{mg} / \mathrm{kg}$ b.wt. $\mathrm{Al}_{2}\left(\mathrm{SO}_{4}\right)_{3}$ revealed bronchopneumonia with congestion, edema of alveoli and blood vessel Fig. (6). The lung tissue composed of thinwalled alveoli. Each alveolus was lined by a single layer of squamous epithelium. There was a thin layer of connective tissue with various blood vessels (interalveolar septum) between the alveoli. Bronchioles lined by cuboidal epithelium were seen leading to the alveoli and surrounded by blood vessels.

Examination of spleen sections of the control group and treated male and female $\mathrm{Al}_{2}\left(\mathrm{SO}_{4}\right)_{3}$ (Fig. 7) revealed normal architecture with its two major components; white pulps and red pulp, separated by marginal zones. The white pulp consisted of follicle with pale germinal center and a peripherally-located central arteriole, surrounded by a sheath of lymphocytes; a periarterial lymphatic sheath. The red pulp was composed of splenic sinuses. 

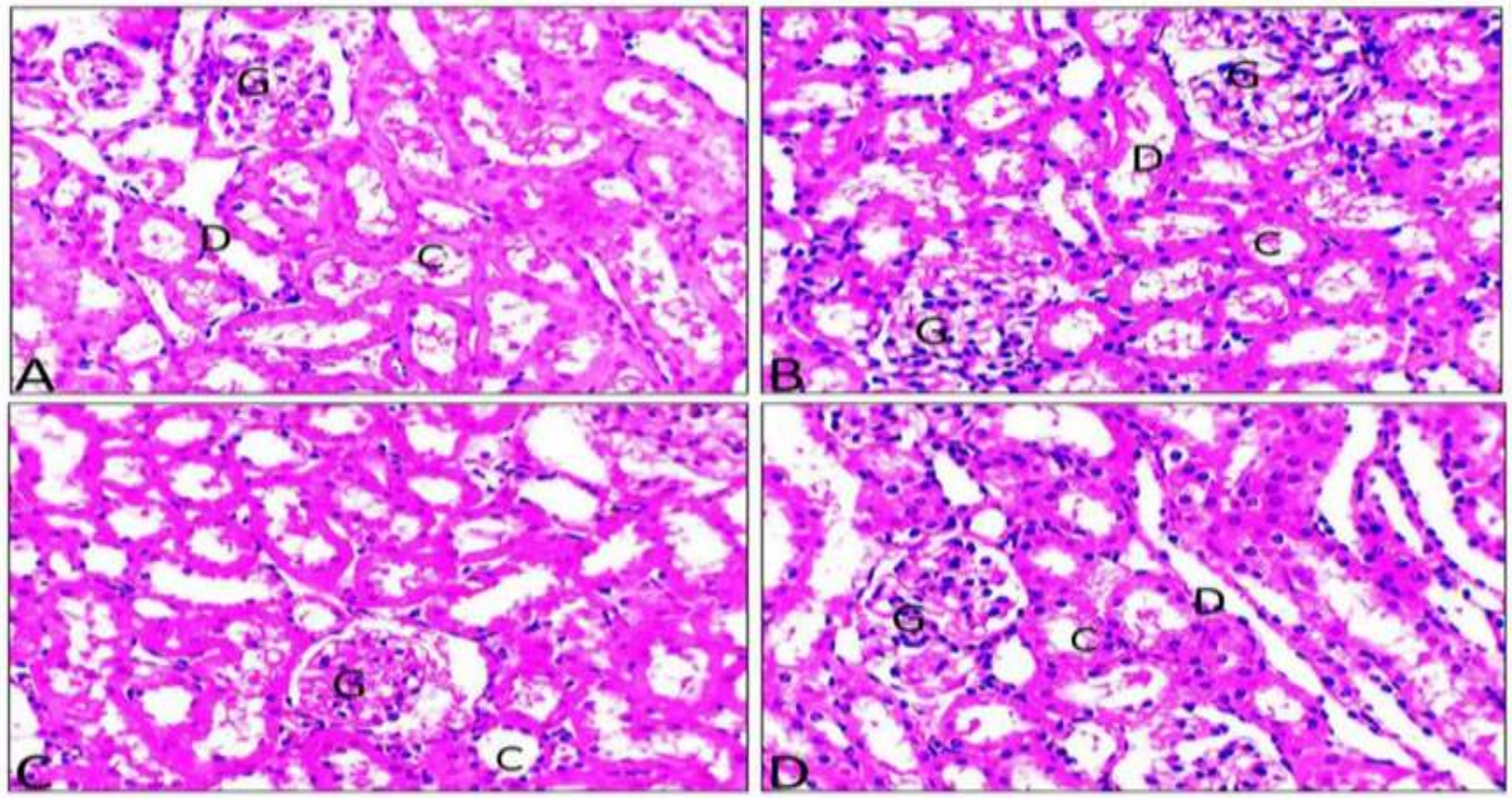

Figure (4): A photomicrograph of kidney section of $(A)$ : Control male rat, $(B)$ : control female rat, treated $(C)$ male rat and (D) female rats IP with $48600 \mathrm{mg} / \mathrm{kg}$ b.wt. $\mathrm{Al}_{2}\left(\mathrm{SO}_{4}\right)_{3}$ showing the normal histological structure of glomerular capillary tufts $(G)$. The Cortical tissue contains proximal (C): and distal convoluted tubules (D): (H\&E X200).
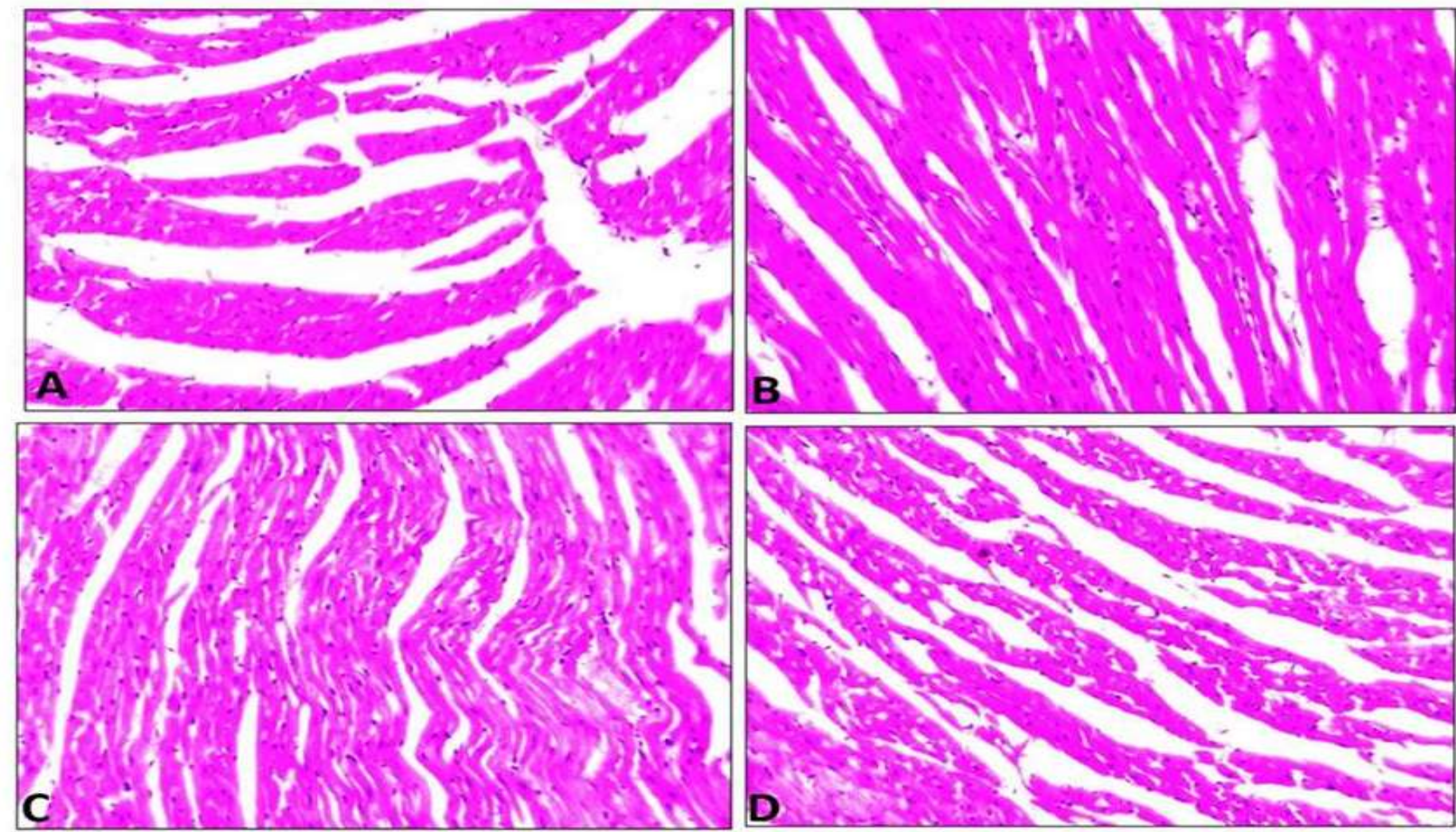

Figure (5): A photomicrograph of heart section of $(A)$ : Control male rat, $(B)$ : control female rat, treated (C): male rat and (D): female rats IP with $48600 \mathrm{mg} / \mathrm{kg}$ b.wt. $\mathrm{Al}_{2}\left(\mathrm{SO}_{4}\right)_{3}$ showing the normal histological architecture of cardiac myocytes. (H\&E X200). 

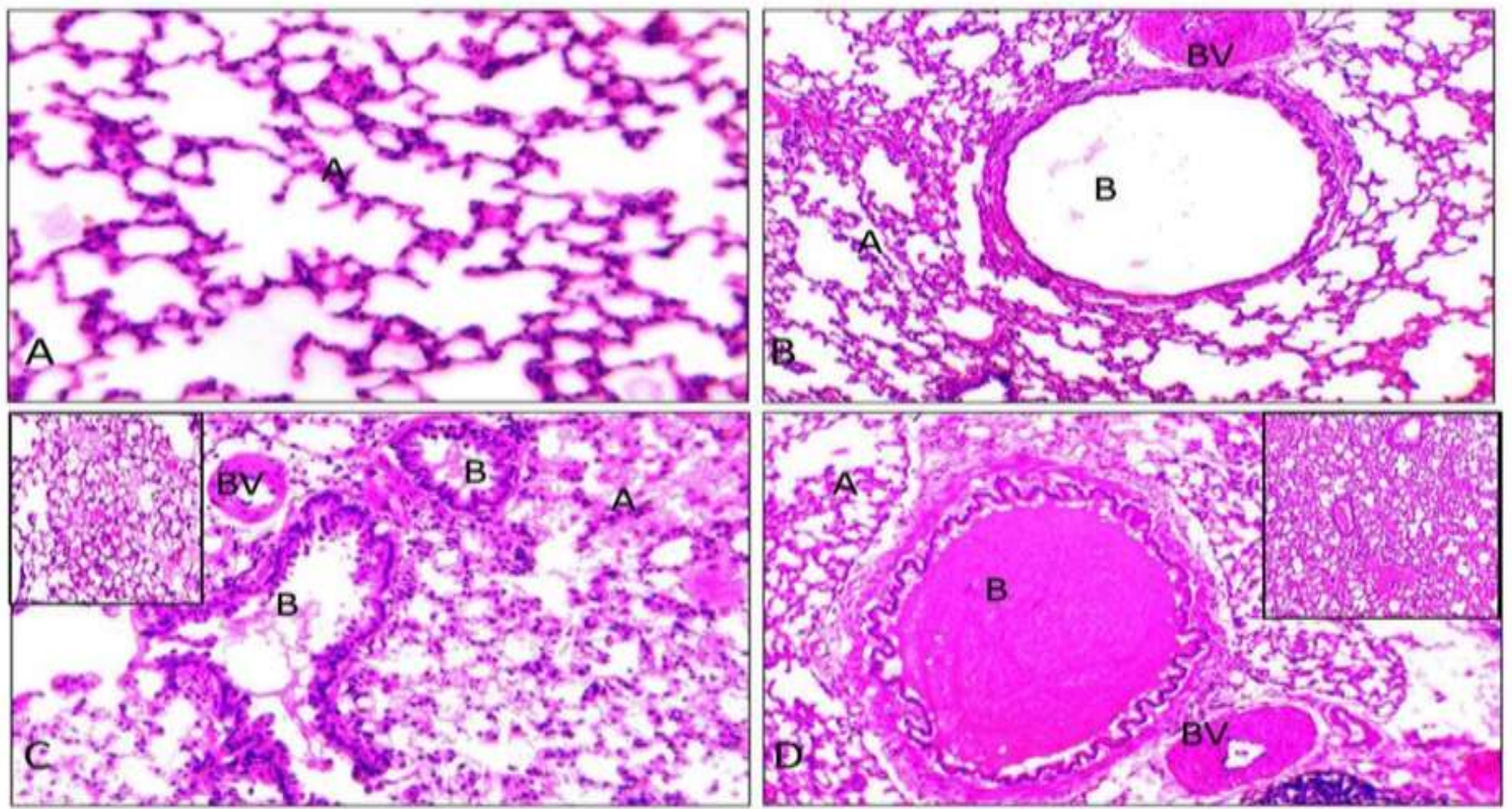

Figure (6): Photomicrograph of a section of the lung from a control from a control $(A)$ : male rat and (B): female rats showing normal histological structure of the thin walled alveoli $(A)$ : separated by interalveolar septa. Bronchiole $(B)$ : is seen surrounded by blood vessels (BV) are seen. Histopathological examination of lung of treated (C): male rat and (D): female rats IP with $48600 \mathrm{mg} / \mathrm{kg}$ b.wt. $\mathrm{Al}_{2}\left(\mathrm{SO}_{4}\right)_{3}$ showing Congestion of the blood vessels (BV) and bronchiole together with extravasation of RBCs. (H\&E X200).
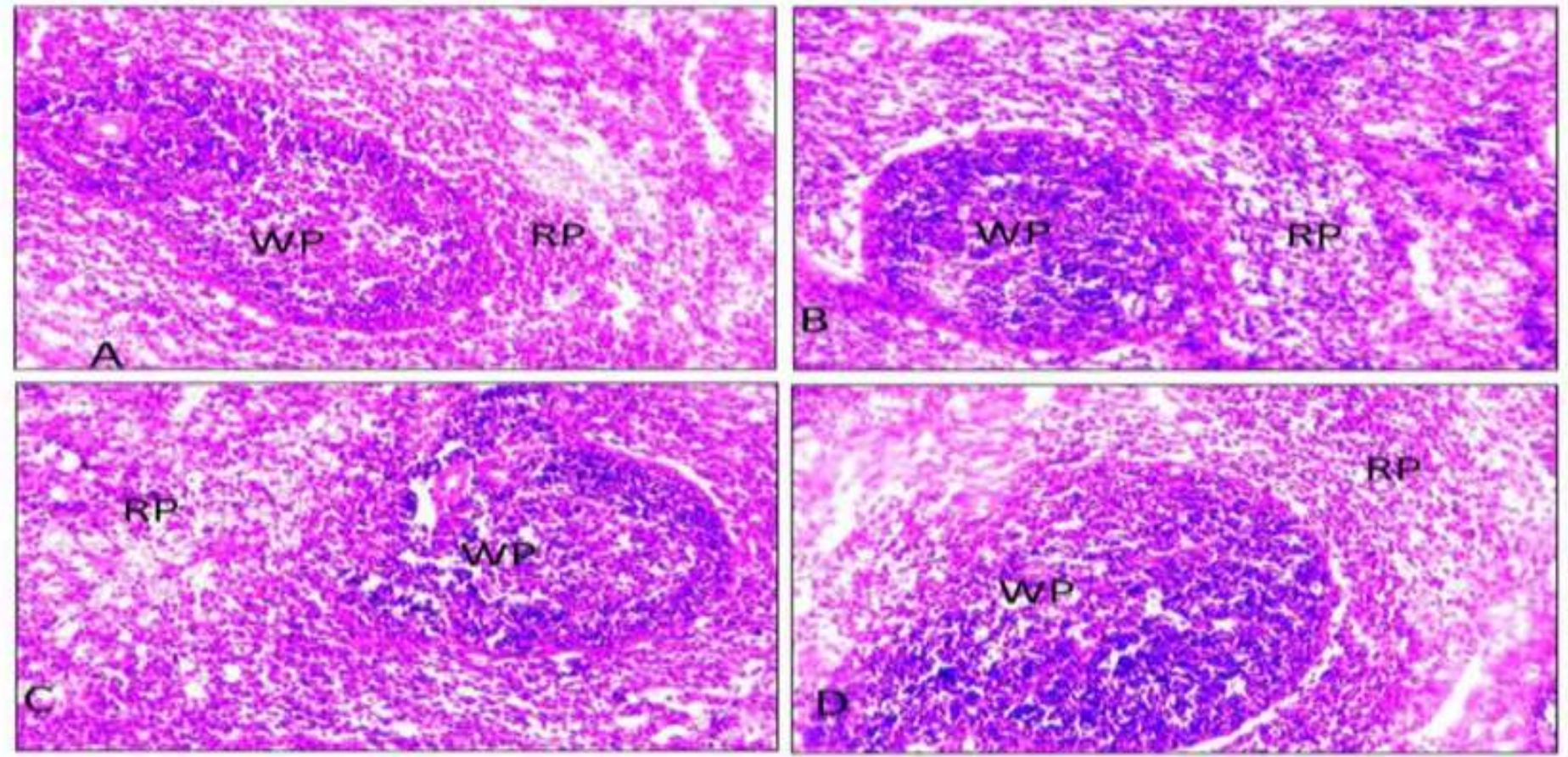

Figure (7): A photomicrograph of Spleen section of $(A)$ : Control male rat, $(B)$ : control female rat, treated (C): male rat and (D): female rats IP with $48600 \mathrm{mg} / \mathrm{kg} \mathrm{b.wt.} \mathrm{Al}_{2}\left(\mathrm{SO}_{4}\right)_{3}$ showing the normal histological architecture of spleen with its two major components; white pulp (WP) and red pulp (RP), separated by marginal zone. (H\&E X200). 

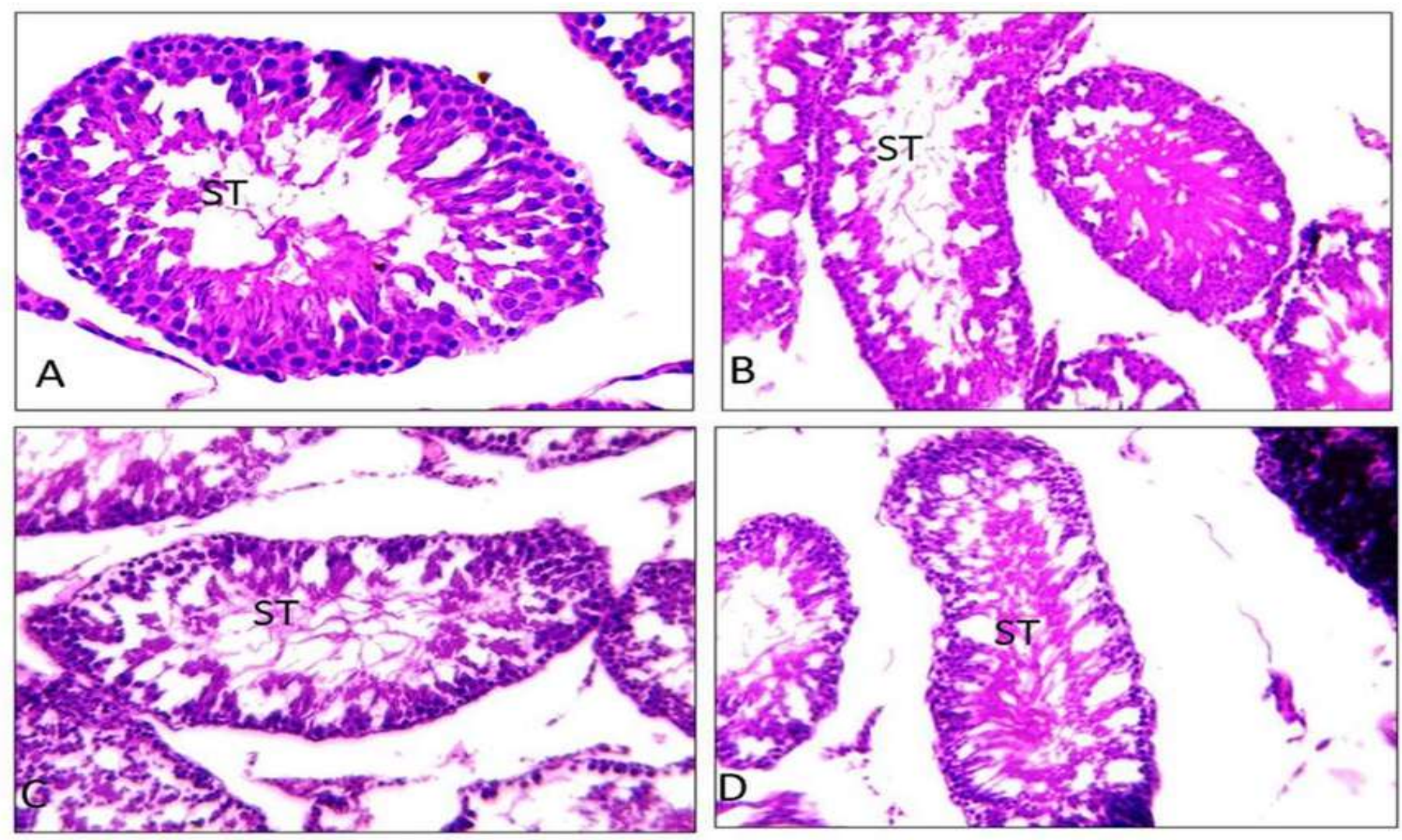

Figure (8): A photomicrograph of a section in the testis of $(A)$ : control rats, $(B)$ : treated male rat IP with $200 \mathrm{mg} / \mathrm{kg} \mathrm{b.wt.}$ $\mathrm{Al}_{2}\left(\mathrm{SO}_{4}\right)_{3}(\mathrm{C})$ : treated male rat IP with $16200 \mathrm{mg} / \mathrm{kg} \mathrm{b.wt.} \mathrm{Al}_{2}\left(\mathrm{SO}_{4}\right)_{3}$ and (D): treated male rat IP with $48600 \mathrm{mg} / \mathrm{kg}$ b.wt. $\mathrm{Al}_{2}\left(\mathrm{SO}_{4}\right)_{3}$ showing the structure of the seminiferous tubules (ST) with the interstitial tissue. (H \& E X 200)

Histological examination of the testicular sections of the control group and treated male with $\mathrm{Al}_{2}\left(\mathrm{SO}_{4}\right)_{3}$ Fig. (8) revealed similar appearance of the seminiferous tubules and interstitial tissue in-between. Sections of the ovaries and uterine of the control group and treated female with $\mathrm{Al}_{2}\left(\mathrm{SO}_{4}\right)_{3}$ revealed the absence of histological damage Fig. (9). Histological findings of the ovaries presented with regular features as shown by the appearance of all types of follicles, healthy vascularity, compact stroma, complete germinal epithelium with normal medulla. Uterine histoarchitecture visualized with a normal endometrial height of the uterus. The uterine glands had normal morphology. The vascularity was rich.

Microscopic examination of the brain cerebral cortex and hippocampus of control rats revealed normal histological structure of the meninges, neurons of the cerebral cortex, and smaller pyramidal cells of the pyramidal layer of the hippocampus Fig. (10). Similar normal structures were found in the brain sections of rats injected IP with $(23,67,200,600$ and 1800) $\mathrm{mg} / \mathrm{kg}$ b.wt. $\mathrm{Al}_{2}\left(\mathrm{SO}_{4}\right)_{3}$ in both sexes. On the other hand, rats injected IP with $(5400,16200,48600) \mathrm{mg} / \mathrm{kg}$ b.wt. $\mathrm{Al}_{2}\left(\mathrm{SO}_{4}\right)_{3}$ exhibited significant degeneration of the cerebral cortex neurons and had no effect on the hippocampus cells Fig. (10).

Histological sections of stomach and small intestine of control male and female rats and rats injected IP with (23, $67,200,600$ and 1800$) \mathrm{mg} / \mathrm{kg}$ b.wt. $\mathrm{Al}_{2}\left(\mathrm{SO}_{4}\right)_{3}$ in both sexes showed normal histoarchitecture Fig. (11). The stomach wall is composed of four main layers, The surface of the mucosa is a layer of columnar epithelial cells and under the present of lamina propria.

Epithelial cells extend down into the lamina propria the gastric glands. The submucosa is lined with areolar connective tissue. The musculature has an outer longitudinal layer and inner layer of circular muscle fibers. The serosa is made up of simple squamous epithelium. Marked histomorphological changes in the mucosa layer were observed in the stomach of treated rats with (5400, $16200,48600) \mathrm{mg} / \mathrm{kg}$ b.wt. $\mathrm{Al}_{2}\left(\mathrm{SO}_{4}\right)_{3}$ characterized by obvious degeneration of tissues, vacuolization in the cytoplasm and pycnotic nuclei.

The small intestine of untreated male and female rats and treated rats with $(23,67,200,600$ and 1800) $\mathrm{mg} / \mathrm{kg}$ b.wt. $\mathrm{Al}_{2}\left(\mathrm{SO}_{4}\right)_{3}$ in both sexes showed normal intestinal histoarchitecture. The mucosa forms villi lining with simple columnar epithelium. Crypts of Liberkuhn throughout the mucosa and Brunner's glands in the sub mucosa were observed. The musculature showed an outer thinner longitudinal and inner thicker circular layers of muscle fibers. Severe histopathological changes were observed in treating rats with $(5400,16200,48600) \mathrm{mg} / \mathrm{kg}$ b.wt. $\mathrm{Al}_{2}\left(\mathrm{SO}_{4}\right)_{3}$ in the form of distortions and vacuolation of villi Fig. (11). 

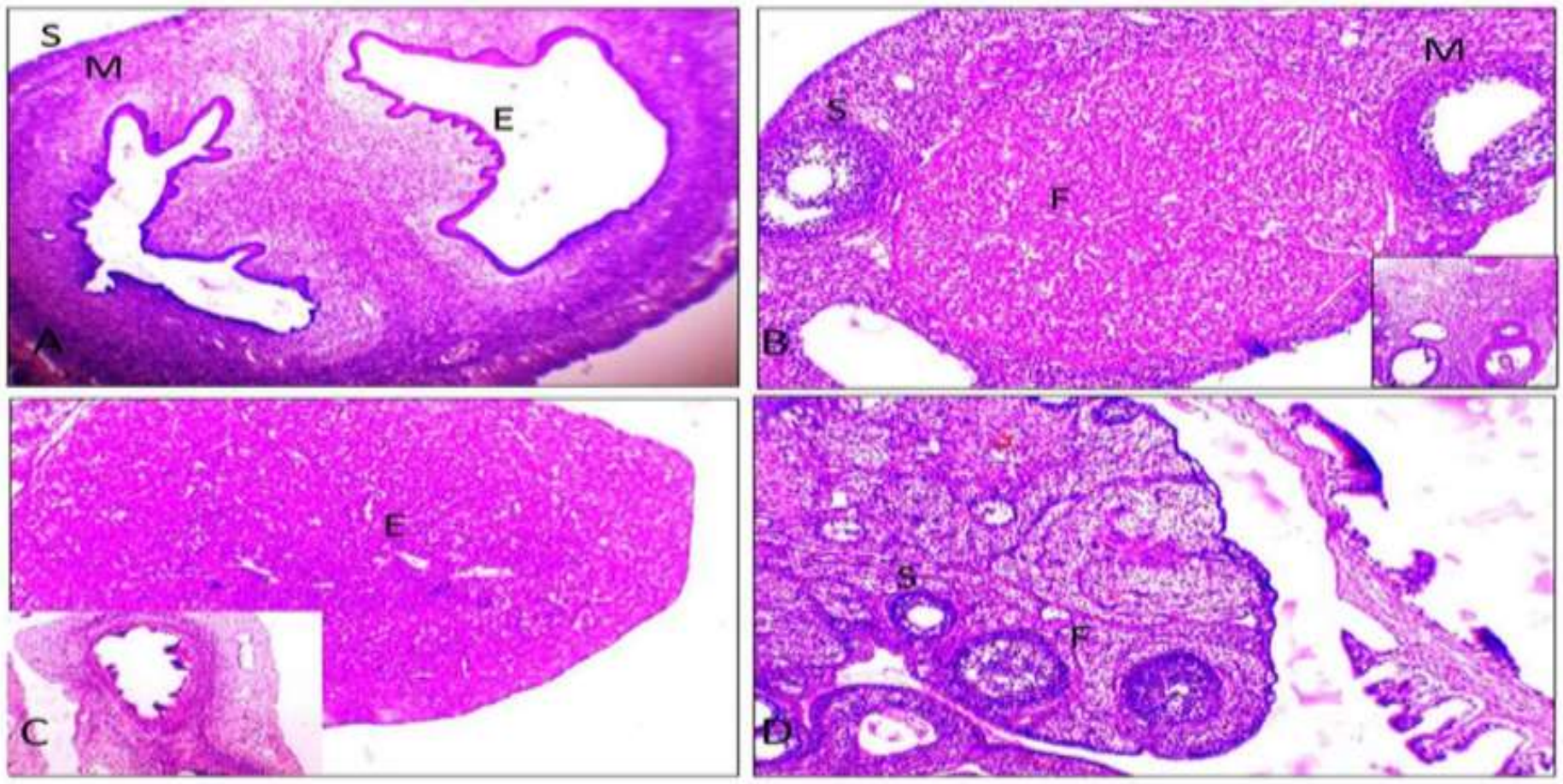

Figure (9): A photomicrograph of $(A)$ the ovaries of control rats (D) the ovaries of treated female rat IP with $48600 \mathrm{mg} / \mathrm{kg}$ b.wt. $\mathrm{Al}_{2}\left(\mathrm{SO}_{4}\right)_{3}$ showing the presence of all types of follicles $(\mathrm{F})$, normal vascularity, compact stroma (S), intact germinal epithelium and normal medulla (M). Histological features of $(B)$ the uterus of rat control rats $(C)$ the uterus of treated female rat IP with $48600 \mathrm{mg} / \mathrm{kg}$ b.wt. $\mathrm{Al}_{2}\left(\mathrm{SO}_{4}\right)_{3}$ showing normal endometrial height (E), normal muscle (M) and serous membrane (S). H \& E X 10.
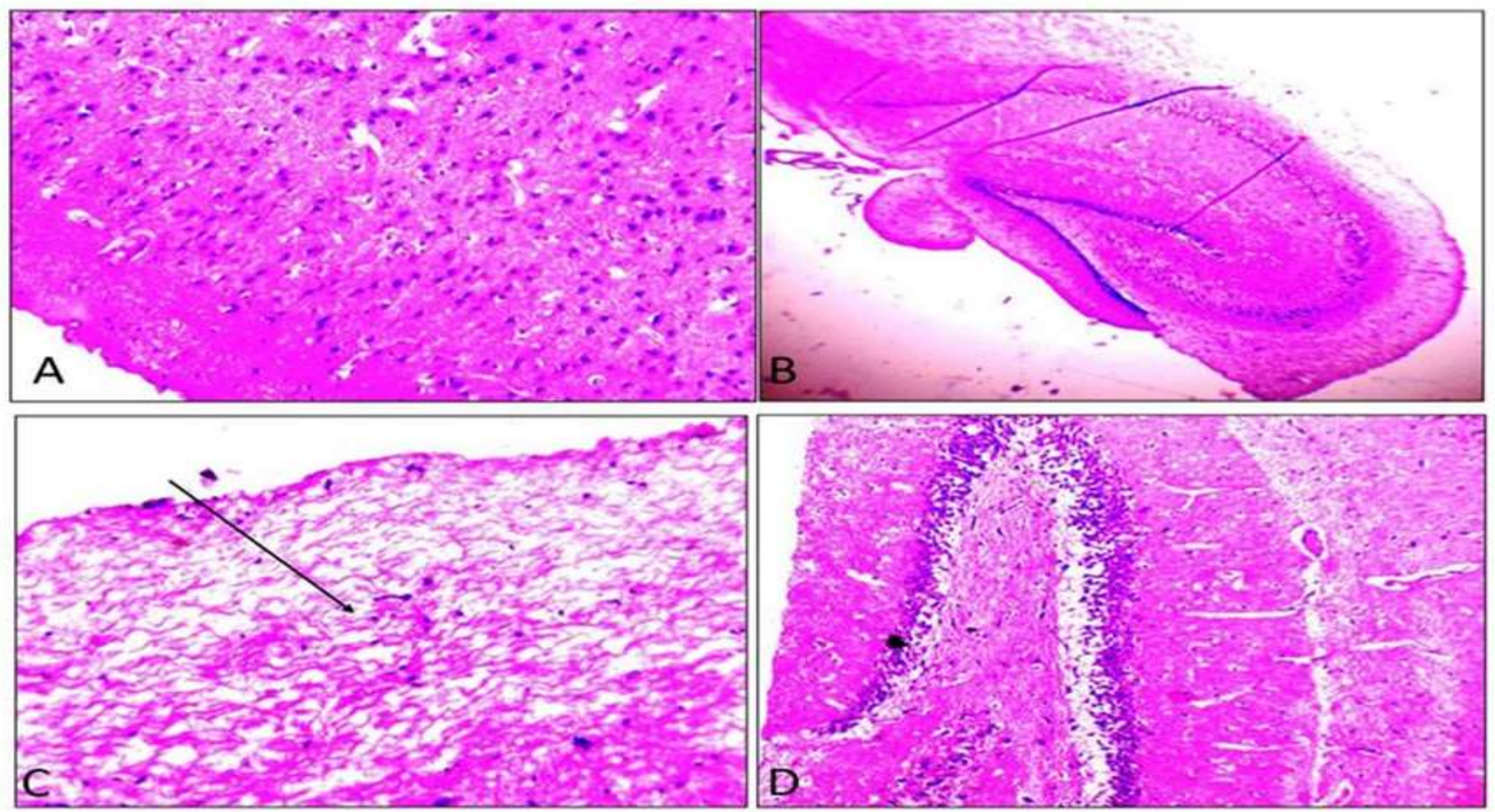

Figure (10): A Photomicrographs of rat brain sections stained with haematoxylin and eosin (A) meninges and cerebral cortex of Control male rat, (C) treated male rats IP with $48600 \mathrm{mg} / \mathrm{kg}$ b.wt. $\mathrm{Al}_{2}\left(\mathrm{SO}_{4}\right)_{3}$ showing severe degeneration of cerebral cortex $(\leftarrow)$. (H\&E X200). Hippocampus of (B) Control male rat, (H\&E X100). (D) treated male rats IP with 48600 $\mathrm{mg} / \mathrm{kg}$ b.wt. $\mathrm{AL}_{2}\left(\mathrm{SO}_{4}\right)_{3}$ showing normal histological structure. (H\&E X200). 

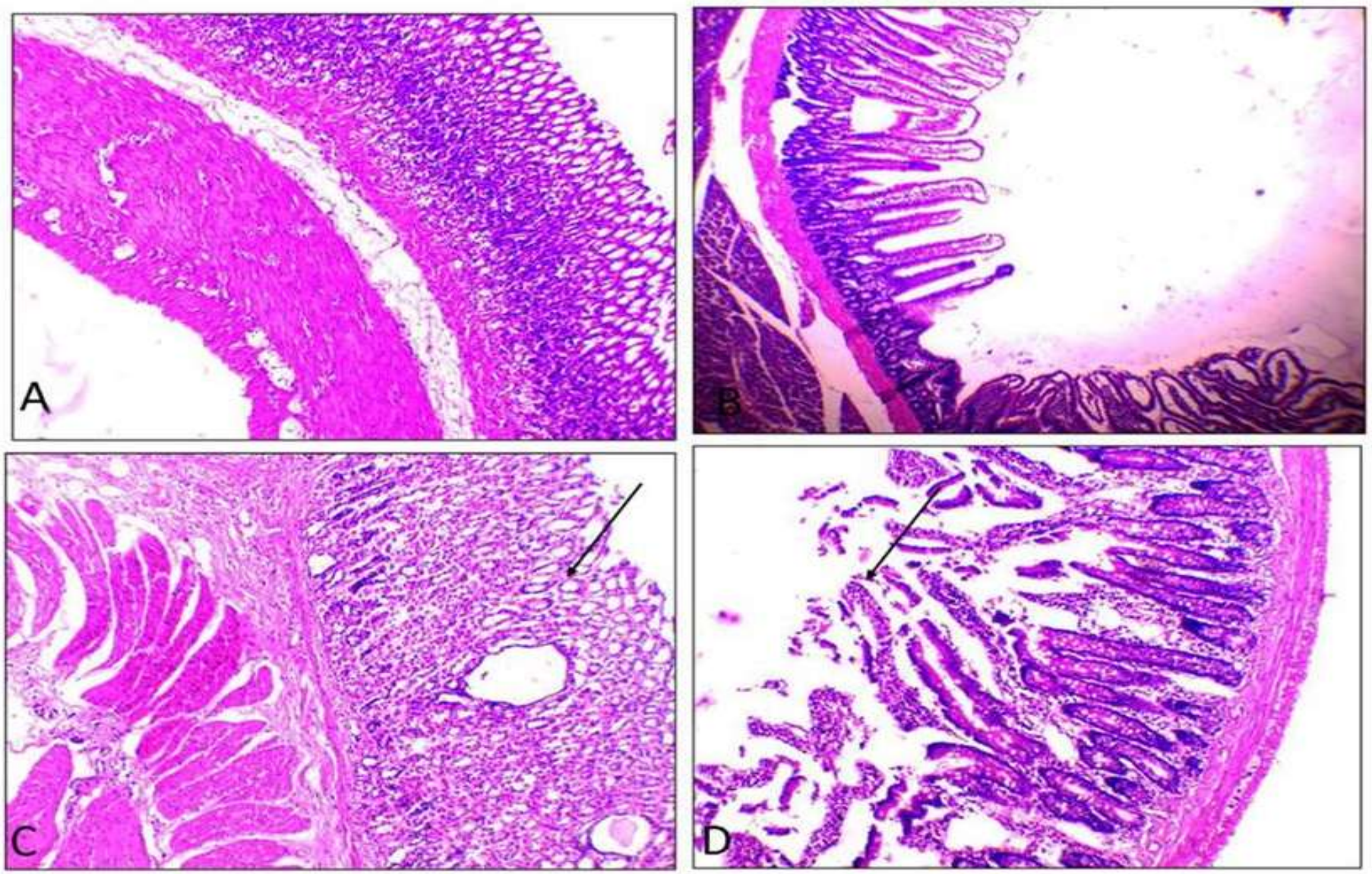

Figure (11): A photomicrograph of $(A)$ Section of stomach of control male rat showing normal histoarchitecture. (C) Treated male rats IP with $48600 \mathrm{mg} / \mathrm{kg}$ b.wt. $\mathrm{Al}_{2}\left(\mathrm{SO}_{4}\right)_{3}$ showing degeneration of mucosa layer, cytoplasmic vacuolization and pycnotic nuclei $(\leftarrow)$. (B) Section of small intestine of control male rat showing normal musculature, villi and crypts of Liberkuhn. (D) Treated male rats IP with $48600 \mathrm{mg} / \mathrm{kg}$ b.wt. $\mathrm{Al}_{2}\left(\mathrm{SO}_{4}\right)_{3}$ showing atrophy, degeneration of villi $(\leftarrow)$. (H\&E X100).

\section{Discussion}

The purpose of this experiment was to study the effects of different single doses of aluminum sulphate on rat organs in a short-term sample. This work shows data on aluminum concentration associated with administering $\mathrm{Al}_{2}\left(\mathrm{SO}_{4}\right)_{3}$ to rats. This study was described by some other authors, but in different conditions (different doses, different route and different time of sampling). The increased absorption of aluminium was also demonstrated by analysis of several tissues. In this work, Intraperitoneal route was selected as the way of $\mathrm{Al}_{2}\left(\mathrm{SO}_{4}\right)_{3}$ administration because it is one of the most neglected routes for testing $\mathrm{Al}_{2}\left(\mathrm{SO}_{4}\right)_{3}$ toxicity. While intraperitoneal distribution is known to be a parenteral route of administration, the pharmacokinetics of substances administered intraperitoneally are more similar to those seen after oral administration. However, intraperitoneal route has the advantage of getting substances into the circulation faster than oral route [21]. This study may be considered a contribution in the estimation of the histological inspection of $\mathrm{Al}_{2}\left(\mathrm{SO}_{4}\right)_{3}$ intraperitoneally administrated in male and female albino rats. As the histological examination of IP injection $\mathrm{Al}_{2}\left(\mathrm{SO}_{4}\right)_{3}$ are not numerous and some were done in relation to the neurotoxicity [22] and reproductive toxicity [23] but in different route of administration.

The most pronounced accumulation of aluminium and histological damage was observed in the lung, stomach, intestine and brain, whereas in other organs the aluminium levels and histological structure were significantly altered only with very high dose of $\mathrm{Al}_{2}\left(\mathrm{SO}_{4}\right)_{3}$.

The toxic symptoms were dose-dependent, as increased by increasing the administrated dose. In this study, liver, lung, cerebral cortex, stomach and intestine were the main target organs of $\mathrm{AL}_{2}\left(\mathrm{So}_{4}\right)_{3}$ histological damage after intraperitoneal dosing of $(5400,16200$, $48600) \mathrm{mg} / \mathrm{kg}$ b.wt. $\mathrm{Al}_{2}\left(\mathrm{SO}_{4}\right)_{3}$. The severity of histological damage of $\mathrm{Al}_{2}\left(\mathrm{SO}_{4}\right)_{3}$ inside rat body organs was correlated to its concentration as it increased by increased the concentration of the injected dose.

As expected, high dose of $\mathrm{Al}_{2}\left(\mathrm{SO}_{4}\right)_{3}$ administration resulted in significant elevations of hepatic aluminium concentrations. Previous studies on aluminum toxicity have shown that the accumulation of aluminum in the liver is correlated with histological changes in liver tissue. [24, 25]. 
Our results, therefore, contribute to our current knowledge of liver histopathology in terms of damage to aluminum and are applicable in cases where liver tissue was collected from male and female rats injected with $\mathrm{Al}_{2}\left(\mathrm{SO}_{4}\right)_{3}$ once time. According to Bogdanović, Janeva et al. (2008) the infiltration of inflammatory cells in the portal area was a defense against $\mathrm{Al}$ metal. The abovementioned findings is in agreement with Bogdanović, Janeva [24] who suggested that injected intraperitoneally Al resulted its accumulation in the liver of experimental rats. Wen, [26] proposed that aluminium in high concentration was toxic to the liver.

Aluminium level in the kidney of treated rats with small doses of $\mathrm{Al}_{2}\left(\mathrm{SO}_{4}\right)_{3}$ showed no significant difference compared to the control animals. This is because the aluminum is excreted through the urine from the body. [27], only the highest dose $\mathrm{Al}_{2}\left(\mathrm{SO}_{4}\right)_{3}$ treated male and female rats accumulate the $\mathrm{Al}$ in the kidney. In addition, the concentration of $\mathrm{Al}$ in the kidneys of $\mathrm{Al}_{2}\left(\mathrm{SO}_{4}\right)_{3}$ treated rats wasnot significantly increased, the kidney appeared normal without pathological changes. The above results are in line with Chagnac, Ben-Bassat [28] who found the absence of histopthological changes of the kidney when Aluminum chloride was injected intraperitoneally at doses of $0.2 \mathrm{mg} /$ day and $2 \mathrm{mg} /$ day for 13 weeks and different from the result obtained [29, 30].

The absence of histological abnormalities in the cardiomyocytes were detected after injection with $\mathrm{Al}_{2}\left(\mathrm{SO}_{4}\right)_{3}$ even the significant increase of aluminum content in the heart of treated male and female rats with the highest dose. The obtained result is different from observed by Ghorbel, Elwej [31] who found that rats received $\mathrm{AlCl}_{3}$ (400 ppm) for 21 days via drinking water induced cardiotoxicity. Novaes, Mouro [32] found that three highest doses of $\mathrm{Al}$ for 120 days induced heart toxicity and Gouda, El-Nabarawy [33] found that aluminium phosphide caused significant cardiac histopathological changes. These results are quite different than current study due to variation in dose and exposure duration.

Determination of aluminum in lung tissue provides strong evidence that the histopathological change of lung corresponds well with the $\mathrm{AL}$ concentration. The pulmonary histopathological damage was restricted to the high doses of $\mathrm{Al}_{2}\left(\mathrm{SO}_{4}\right)_{3}$. The present work revealed loss of the normal alveolar architecture in response to the high dose of aluminum administration. This result could be explained in accordance with Riihimäki and Aitio [34] who proposed that the produced lesion is produced due to the lung epithelium is the site for the accumulation of aluminum and a surface for its uptake into lung tissues. Also, congested blood vessels with extravasations of RBCs and hemorrhage were also observed in lung sections of a rat injected with higher doses of $\mathrm{Al}_{2}\left(\mathrm{SO}_{4}\right)_{3}$ in the present work. Similar results were observed by Buraimoh and Ojo [35] in aluminum treated rats.

In the present study, aluminium content in spleen was significantly increased in male and female rats with 48600 $\mathrm{mg} / \mathrm{kg}$ b.wt. $\mathrm{Al}_{2}\left(\mathrm{SO}_{4}\right)_{3}$ compared to that of control groups.
This aluminum content not reflected on the histopathology of the spleen in the treated groups. This contradict with Stein, Laske [36] and HM, Hassan [37] that who reported that high doses of aluminum induced damage to the spleen of the rats.

The present study showed that the experimental treated rats $\mathrm{Al}_{2}\left(\mathrm{SO}_{4}\right)_{3}$ showd no testicular lesions and no accumulation of aluminum in the testicular tissue.

Single IP injection of $\mathrm{Al}_{2}\left(\mathrm{SO}_{4}\right)_{3}$ showed virtually no influence on adult females' reproductive histology (uterine and ovarian tissue) with nonsignificant accumulation of aluminum in both organs. This result is in agreement with Miska-Schramm, Kapusta [41] and disagreewith Trif, Dumitrescu [42] who found uterine and ovarian histological damage in receiving $\mathrm{Al}_{2}\left(\mathrm{SO}_{4}\right)_{3}$ in water during pregnancy until sexual maturity of the female rats.

Much focus has so far been paid to experimental research on neurotoxic effects in Al. Mechanistic studies of aluminum neurotoxicity have been performed [43]. In the present study, sections of the cerebral cortex and hippocampus were prepared from control and $\mathrm{Al}_{2}\left(\mathrm{SO}_{4}\right)_{3}$ treated male and female rats were histologically examined in order to describe any observed changes and aluminium content in the forebrain. The aluminium content was significantly increased even in small dose used of $\mathrm{Al}_{2}\left(\mathrm{SO}_{4}\right)_{3}$ and that agree with Abubakar, Taylor [44] that found the amounts of brain tissue aluminum detected were increased in all brain regions examined in rats given an intraperitoneal injection of $10 \mathrm{mg} / \mathrm{kg}$ body weight aluminum lactate and Baydar, Papp [45] found that brain tissue levels of aluminum were increased when a low $(50 \mathrm{mg} / \mathrm{kg} / \mathrm{d})$ or high $(200 \mathrm{mg} / \mathrm{kg}$ / d) dose of aluminum chloride was applied to male Wistar rats by gavage for 8 weeks. Histological changes are found in the cerebral cortex of $\mathrm{Al}_{2}\left(\mathrm{SO}_{4}\right)_{3}$ treated groups compared to the control groups. Severity of damage increase by increasing the treatment dose. This research work has demonstrated that rats treated once with $\mathrm{Al}_{2}\left(\mathrm{SO}_{4}\right)_{3}$ and left for 2 weeks resulted in neuronal degeneration of the cerebral cortex. The hippocampus of male and female rat not affected histologically with the single injection of higher dose of $\mathrm{Al}_{2}\left(\mathrm{SO}_{4}\right)_{3}$ and that disagree with Yuan, Lee [46] who reported the excess of $\mathrm{AL}$ accumulates in the brain hippocampus, in rats after intraperitoneal injection of high levels of Al showed hippocampus damage. Çabuş, Oğuz [47] Found $3 \mathrm{mg} / \mathrm{ml}$ of aluminum sulfate injected IP rats everyday for two weeks of toxic effects of aluminum on hippocampus rats. Kamel and Mostafa [48] Found histologically and ultrastructure damage of hippocampous of rat received aluminum chloride added to water for 8 weeks.

In the present study, single IP injection of higher doses of $\mathrm{Al}_{2}\left(\mathrm{SO}_{4}\right)_{3}$ resulted in significant aluminum content increase histopathological anomalies in the stomach and small intestines. Similar effects of aluminium on the mucosa were reported by Pineton de Chambrun, BodyMalapel [49], Buraimoh and Ojo [50], Eltahawy, Sarhan [51]. As the majority of aluminium that enters the 
gastrointestinal tract excreted in the faeces [52] and that can make it a chance to accumulate.

\section{Conclusion}

Overall, the results of this study showed that animals were typically tolerant to $(23,67,200,600,1800) \mathrm{mg} / \mathrm{kg}$ b.wt. $\mathrm{Al}_{2}\left(\mathrm{SO}_{4}\right)_{3}$ but substantially reacts to higher doses (5400, 16200, 48600) mg / kg b.wt. $\mathrm{Al}_{2}\left(\mathrm{SO}_{4}\right)_{3}$.

Short term use of $(23,67,200,600,1800) \mathrm{mg} / \mathrm{kg}$ b.wt. $\mathrm{Al}_{2}\left(\mathrm{SO}_{4}\right)_{3}$ is safe and induce mild histopathological alteration for the different body organ. On the other hand, severe histopathologial alteration synchronized with aluminum accumulation in the body organ induced by using a single dose of $(5400,16200,48600) \mathrm{mg} / \mathrm{kg}$ b.wt. $\mathrm{Al}_{2}\left(\mathrm{SO}_{4}\right)_{3}$. Thus, the data presented in this study are very useful for the utilization of experimental model in short term study with the higher doses.

\section{Abbreviations:}

$\mathrm{Al}_{2}\left(\mathrm{SO}_{4}\right)_{3}$ : Aluminium sulfate

b.wt.: body weight

Al: Aluminium

\section{References:}

[1] Said MM, Abd Rabo MM. Neuroprotective effects of eugenol against aluminiuminduced toxicity in the rat brain. Arhiv za higijenu rada i toksikologiju. 2017;68:27-36.

[2] Yokel RA. The toxicology of aluminum in the brain: a review. Neurotoxicology. 2000;21:813-28.

[3] Walton J. An aluminum-based rat model for Alzheimer's disease exhibits oxidative damage, inhibition of PP2A activity, hyperphosphorylated tau, and granulovacuolar degeneration. Journal of inorganic biochemistry. 2007;101:1275-84.

[4] Niedworok J, Fijałkowski P. Effect of Long-Term Aluminium Chloride Intoxication on Selected Biochemical Parameters and Oxidative--Antioxidative Balance in Experimental Animals. Polish Journal of Environmental Studies. 2004;13:41-3.

[5] Aziz I, Zabut BM. Determination of blood indices of albino rats treated with aluminum chloride and investigation of antioxidant effects of vitamin $E$ and $C$. Egyptian Journal of Biology. 2011;13:1-7.

[6] Abubakar M, Taylor A, Ferns G. Aluminium administration is associated with enhanced hepatic oxidant stress that may be offset by dietary vitamin $E$ in the rat. International journal of experimental pathology. 2003;84:49-54.

[7] Campbell A. The potential role of aluminium in Alzheimer's disease. Nephrology Dialysis Transplantation. 2002;17:17-20.

[8] Kumar V, Gill KD. Aluminium neurotoxicity: neurobehavioural and oxidative aspects. Archives of toxicology. 2009;83:965-78.

[9] El-Rahman SSA. Neuropathology of aluminum toxicity in rats (glutamate and GABA impairment). Pharmacological Research. 2003;47:189-94.

[10] Ebina Y, Okada S, Hamazaki S, Midorikawa O. Liver, kidney, and central nervous system toxicity of aluminum given intraperitoneally to rats: a multiple-dose subchronic study using aluminum nitrilotriacetate. Toxicology and applied pharmacology. 1984;75:211-8.

[11] Mahor G, Ali SA. Protective effects of Aloe vera extract on aluminium sulphate induced alterations in serum lipid profile of male albino rats, Rattus norvegicus. BIOSCIENCE BIOTECHNOLOGY RESEARCH COMMUNICATIONS. 2018;11:727-33.

[12] Llobet JM, Colomina MT, Sirvent JJ, Domingo JL, Corbella J. Reproductive toxicology of aluminum in male mice. Fundamental and applied toxicology. 1995;25:45-51.
[13] Stacchiotti A, Rodella L, Ricci F, Rezzani R, Lavazza A, Bianchi R. Stress proteins expression in rat kidney and liver chronically exposed to aluminium sulphate. Histology and histopathology. 2006;21:131.

[14] Langmyhr FJ, Tsalev DL. Atomic absorption spectrometric determination of aluminium in whole blood. Analytica Chimica Acta. 1977;92:79-83.

[15] EL-Hak HNG, Moustafa ARA, Mansour SR. Toxic effect of Moringa peregrina seeds on histological and biochemical analyses of adult male Albino rats. Toxicology reports. 2018;5:38-45.

[16] Gad El-Hak HN, Mobarak YM. The neurotoxic impact of subchronic exposure of male rats to copper oxychloride. Journal of Trace Elements in Medicine and Biology. 2019;52:186-91.

[17] El-Hak HNG, Mobarak YM. The ameliorative impacts of curcumin on copper oxychloride-induced hepatotoxicity in rats. The Journal of Basic and Applied Zoology. 2018;79:44.

[18] Radunović A, Bradbury MW, Delves HT. Determination of aluminium in different tissues of the rat by atomic absorption spectrometry with electrothermal atomization. Analyst. 1993;118:533-6.

[19] Belarra MA, Azofra MC, Anzano JM, Castillo JR. Determination of metals in poly (vinyl chloride) by atomic absorption spectrometry. Part 4. Determination of lead and aluminium in samples of poly (vinyl chloride) with a high content of silicates. Journal of Analytical Atomic Spectrometry. 1989;4:101-3.

[20] Elmer P. Analytical methods for atomic absorption spectroscopy. USA: The Perkin-Elmer Corporation. 1996.

[21] Turner PV, Brabb T, Pekow C, Vasbinder MA. Administration of substances to laboratory animals: routes of administration and factors to consider. Journal of the American Association for Laboratory Animal Science. 2011;50:600-13.

[22] Cabus N, Oguz EO, Tufan AC, Adiguzel E. A histological study of toxic effects of aluminium sulfate on rat hippocampus. Biotechnic \& histochemistry : official publication of the Biological Stain Commission. 2015;90:132-9.

[23] Muselin F, Cristina RT, Igna V, Dumitrescu E, Brezovan D, Trif $A$. The consequences of aluminium intake on reproductive function in male rats: a three-generation study. Turkish journal of medical sciences. 2016;46:1240-8.

[24] Bogdanović M, Janeva A, Bulat P. Histopathological changes in rat liver after a single high dose of aluminium. Archives of Industrial Hygiene and Toxicology. 2008;59:97-101.

[25] Berlyne G, Ari JB, Knopf E, Yagil R, Weinberger G, Danovitch G. Aluminium toxicity in rats. The Lancet. 1972;299:564-8.

[26] Wen Y-F, J-QZ, Nirala SK, MB. Aluminum-Induced Toxicity and Its Response to Combined Treatment of HEDTA and Propolis in Rats. Pol J Environ Stud. 2012;21:1437-43.

[27] Genuis SJ, Birkholz D, Rodushkin I, Beesoon S. Blood, urine, and sweat (BUS) study: monitoring and elimination of bioaccumulated toxic elements. Archives of environmental contamination and toxicology. 2011;61:344-57.

[28] Chagnac A, Ben-Bassat M, Weinstein T, Levi J. Effect of long-term aluminum administration on the renal structure of the rat. Nephron. 1987;47:66-9.

[29] Geyikoglu F, Türkez H, Bakir TO, Cicek M. The genotoxic, hepatotoxic, nephrotoxic, haematotoxic and histopathological effects in rats after aluminium chronic intoxication. Toxicology and industrial health. 2013;29:780-91.

[30] Kutlubay R, Oğuz EO, Güven C, Can B, Sinik Z, Tuncay ÖL. Histological and ultrastructural evidence for protective effects on aluminium-induced kidney damage by intraperitoneal administration of $\alpha$-Tocopherol. International journal of toxicology. 2007;26:95-101. 
[31] Ghorbel I, Elwej A, Chaabane M, Jamoussi K, Zeghal N. Protective effect of selenium against aluminium chloride induced cardiotoxicity in rats. Pharmaceutical and Biomedical Research. 2017;3:19-25.

[32] Novaes RD, Mouro VGS, Gonçalves RV, Mendonça AAS, Santos EC, Fialho $M C Q$, et al. Aluminum: A potentially toxic metal with dose-dependent effects on cardiac bioaccumulation, mineral distribution, DNA oxidation and microstructural remodeling. Environmental Pollution. 2018;242:814-26.

[33] Gouda AS, El-Nabarawy NA, Ibrahim SF. Moringa oleifera extract (Lam) attenuates Aluminium phosphide-induced acute cardiac toxicity in rats. Toxicology Reports. 2018;5:209-12.

[34] Riihimäki V, Aitio A. Occupational exposure to aluminum and its biomonitoring in perspective. Critical reviews in toxicology. 2012;42:827-53.

[35] Buraimoh A, Ojo S. Effects of aluminium chloride exposure on the histology of lungs of wistar rats. Journal of Applied Pharmaceutical Science. 2013;3:18.

[36] Stein G, Laske V, Müller A, Bräunlich H, Linß W, Fleck C. Aluminium induced damage of the lysosomes in the liver, spleen and kidneys of rats. Journal of Applied Toxicology. 1987;7:253-8. [37] HM O, Hassan KA, Kh A-ES, EA A. Aluminium toxicity in rats: The role of tannic acid as antioxidant. Ass Univ Bull Environ Res. 2003;6.

[38] Abdel-Moneim AM. Effects of taurine against histomorphological and ultrastructural changes in the testes of mice exposed to aluminium chloride. Archives of Industrial Hygiene and Toxicology. 2013;64:405-14.

[39] Yousef MI, Salama AF. Propolis protection from reproductive toxicity caused by aluminium chloride in male rats. Food and Chemical Toxicology. 2009;47:1168-75.

[40] Buraimoh AA, Ojo SA, Hambolu JO, Adebisi SS. Histological study of the effects of aluminium chloride exposure on the testis of wistar rats. American International Journal of Contemporary Research. 2012;2:114-22.

[41] Miska-Schramm A, Kapusta J, Kruczek M. The Effect of Aluminum Exposure on Reproductive Ability in the Bank Vole (Myodes glareolus). Biological trace element research. 2017;177:97-106.

[42] Trif A, Dumitrescu E, Brezovan D, Petrovici S. The consequences of aluminium sulphate intake on exposure and integrity biomarkers in female rats at sexual maturity (two generation study). Human and Veterinary Medicine. 2010;2:11-7. [43] Wang X, Cheng D, Jiang W, Ma Y. Mechanisms Underlying Aluminum Neurotoxicity Related to $14-3-3 \zeta$ Protein. Toxicological Sciences. 2018;163:45-56.

[44] Abubakar MG, Taylor A, Ferns GAA. Regional accumulation of aluminium in the rat brain is affected by dietary vitamin $E$. Journal of Trace Elements in Medicine and Biology. 2004;18:539.

[45] Baydar T, Papp A, Aydin A, Nagymajtenyi L, Schulz H, Isimer $A$, et al. Accumulation of aluminum in rat brain. Biological Trace Element Research. 2003;92:231-44.

[46] Yuan C-Y, Lee Y-J, Hsu G-SW. Aluminum overload increases oxidative stress in four functional brain areas of neonatal rats. J Biomed Sci. 2012;19:51-.

[47] Çabuş N, Oğuz E, Tufan A, Adıgüzel E. A histological study of toxic effects of aluminium sulfate on rat hippocampus. Biotechnic \& Histochemistry. 2015;90:132-9.

[48] Kamel ES, Mostafa N. Effect of aluminum chloride on the hippocampus of adult rats and the possible protective role of Nigella sativa: a histological and immunohistochemical study. Egyptian Journal of Histology. 2013;36:505-13.

[49] Pineton de Chambrun G, Body-Malapel M, Frey-Wagner I, Djouina $M$, Deknuydt $F$, Atrott $K$, et al. Aluminum enhances inflammation and decreases mucosal healing in experimental colitis in mice. Mucosal Immunology. 2013;7:589.

[50] Buraimoh A, Ojo S. Effects of aluminium chloride exposure on the histology of the small intestine of Wistar rats. International Journal of Applied. 2012;2.

[51] Eltahawy NA, Sarhan OM, Hammad AS, Abu-nour S. Effects of combined exposure to aluminum chloride and $\mathrm{Y}$ radiation on histological and ultrastructure of intestinal Paneth cells. Journal of Radiation Research and Applied Sciences. 2016;9:400-8.

[52] Exley C. Human exposure to aluminium. Environmental Science: Processes \& Impacts. 2013;15:1807-16. 